\title{
Penyuluhan Hukum Di Kecamatan Mojogedang Kabupaten Karanganyar Dalam Rangka Meningkatkan Mutu Hukum Melalui Sosialisasi Bantuan Hukum
}

\author{
Legal Counseling In Mojogedang Village, Mojogedang District, \\ Karanganyar Regency In The Context Of Improving Legal Quality \\ Through The Socialization Of Legal Aid
}

\author{
Marisa Kurnianingsih ${ }^{1}$, Rokhman Adi Putera Nugraha ${ }^{2}$, Aristya Windiana Pamuncak ${ }^{3}$ \\ ${ }^{123}$ Fakultas Hukum Universitas Muhammadiyah Surakarta \\ E-mail: ${ }^{1}$ mk122@ ums.ac.id ; ${ }^{2}$ rokhmanadi19012000@gmail.com ; ${ }^{3}$ awp188@ums.ac.id \\ Korespondensi author : mk122@ums.ac.id (085725151010)
}

Received: 1 Januari 2021; Revision: 10 Februari 2021; Accepted: 30 Maret 2021

\begin{abstract}
Abstrak
Bantuan Hukum adalah jasa hukum yang diberikan oleh Pemberi Bantuan Hukum secara cuma-cuma kepada Penerima Bantuan Hukum. Berpijak pada dasar konstitusi bangsa Indonesia yang bertujuan untuk menjamin hak konstitusional setiap orang untuk mendapatkan pengakuan, jaminan, perlindungan, dan kepastian hukum yang adil serta perlakuan yang sama di hadapan hukum sebagai sarana perlindungan hak asasi manusia, dimana hal tersebut merupakan salah satu wujud untuk melindungi hak masyarakat dan wujud negara dalam bertanggung jawab atas pemberian bantuan hukum bagi orang miskin sebagai perwujudan akses terhadap keadilan. Tujuan dari kegiatan penyuluhan hukum adalah untuk memberikan keterampilan sekaligus pemahaman tentang bantuan hukum dan cara memperolehnya bagi masyarakat di Desa Mojogedang, Kecamatan Mojogedang Kabupaten Karanganyar. Metode yang digunakan dalam kegiatan ini adalah sosialisasi yang kemudian dilanjutkan dengan pendampingan hukum untuk masyarakat di Kecamatan Mojogedang Kabupaten Karanganyar.

Kata Kunci: Bantuan Hukum; Mojogedang; Sosialisasi.
\end{abstract}

\begin{abstract}
Abstrack
Legal aid is legal services provided by legal aid providers free of charge to legal aid recipients. Based on the basic constitution of the Indonesian nation which aims to guarantee the constitutional rights of everyone to get recognition, guarantee, protection, and legal certainty that is just and equal treatment before the law as a means of protecting human rights, where this is one form of protecting community rights and the form of the state in being responsible for providing legal aid for the poor as a manifestation of access to justice. The purpose of the legal counseling activity is to provide skills as well as an understanding of legal aid and how to obtain it for the community in Mojogedang village, Mojogedang District, Karanganyar Regency. The method used in this activity is socialization which is then followed by legal assistance for the community in Mojogedang District, Karanganyar Regency.
\end{abstract}

Keywords: Legal Aid; Mojogedang; Socialization.

This is an open access article under the CC-BY-SA license.

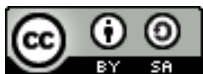

PENDAHULUAN

Pembangunan hukum sebagai bagian integral dari sistem pembangunan nasional, secara strategis merupakan landasan dan menjadi perekat bidang pembangunan lainnya serta sebagai faktor integratif, dalam kehidupan berbangsa dan bernegara dalam bingkai NKRI melalui pembangunan 
sistem hukum nasional berdasarkan Pancasila dan Undang-Undang Dasar Negara Republik Indonesia tahun 1945.(Sudjana, 2016) Pelaksanaan pembangunan hukum harus dilakukan secara komprehensif mencakup substansi hukum, kelembagaan hukum dan budaya hukum serta dibarengi dengan penegakan hukum secara tegas dan konsisten dengan tetap menjunjung tinggi hak asasi manusia, sehingga aktualisasi fungsi hukum sebagai sarana pembaharuan dan pembangunan, instrumen penyelesaian masalah secara adil serta sebagai pengatur perilaku masyarakat untuk menghormati hukum dapat tercapai.(Laili, 2016)

Pembukaan UUD 1945 alenia 4 (empat) telah ditegaskan bahwa “... kemudian daripada itu untuk membentuk suatu pemerintah negara Indonesia yang melindungi segenap bangsa Indonesia dan seluruh tumpah darah Indonesia dan untuk memajukan kesejahteraan umum, mencerdaskan kehidupan bangsa, dan ikut melaksanakan ketertiban dunia yang berdasarkan kemerdekaan, perdamaian abadi, dan keadilan sosial ..." dari penegasan tersebut sebuah pemahaman tentang kewajiban negara menjamin hak konstitusional setiap orang untuk mendapatkan pengakuan, jaminan, perlindungan, dan kepastian hukum yang adil serta perlakuan yang sama di hadapan hukum sebagai sarana perlindungan HAM, selain daripada hal tersebut juga menjadi sarana kepada masyarakat mengenai bantuan hukum yang mana negara berorientasi pada terwujudnya perubahan sosial yang berkeadilan.

Dari yang diamanahkan dalam konstitusi tersebut yang pada akhirnya membuat Tim Pengabdian Kepada Masyarakat tergerak untuk ikut andil dalam mensukseskan cita-cita negara yang telah diamanahkan dalam Pembukaan UUD 1945 alenia 4 (empat). Dalam hal ini kegiatan yang dilaksanakan ialah berupa pemberdayaan masyarakat dimana berwujud penyuluhan hukum. Secara definisi pemberdayaan masyarakat dapat dilihat dalam peraturan perundang-undangan yakni UndangUndang Nomor 6 Tahun 2014 Tentang Desa dimana didefinisikan sebagai berikut:

"Pemberdayaan Masyarakat Desa adalah upaya mengembangkan kemandirian dan kesejahteraan masyarakat dengan meningkatkan pengetahuan, sikap, keterampilan, perilaku, kemampuan, kesadaran, serta memanfaatkan sumber daya melalui penetapan kebijakan, program, kegiatan dan pendampingan yang sesuai dengan esensi masalah dan prioritas kebutuhan masyarakat Desa" adapun dari hal tersebut dibentuk dengan tujuan untuk melaksanakan pembangunan desa yang partisipatif dan berkesinambungan serta mensinergikan pembangunan dan pemberdayaan masyarakat desa dengan program pemerintah dan pemerintah daerah.

Berkenaan dengan permasalahan dan prioritas kebutuhan masyarakat Tim Pengabdian Kepada Masyarakat telah melakukan sebuah survei terhadap permasalahan yang dialami oleh masyarakat di Desa Mojogedang, Kecamatan Mojogedang Kabupaten Karanganyar.(Republik Indonesia, 2012) Adapun Desa Mojogedang sendiri merupakan salah satu desa dari 13 (tiga belas) desa yang terletak di Kecamatan Mojogedang Kabupaten Karanganyar yang luas wilayahnya berkisar 378,42 Ha, dengan jumlah penduduk 3.693 orang.(BK Karanganyar, 2019)

Berdasarkan hasil survei tersebut kemudian dapat disimpulkan bahwa terdapat kebutuhan di Desa Mojogedang, Kecamatan Mojogedang yang berupa sosialisasi hukum berkenaan dengan bantuan hukum. Hal ini dikarenakan masyarakat di Kecamatan Mojogedang pada umumnya dan Desa Mojogedang pada khususnya masih sangat awam dengan sebuah lembaga bantuan hukum, yang dianggapnya bilamana seseorang tidak mempunyai finansial yang baik maka tidak dapat memperoleh sebuah bantuan hukum, pengacara, dan advokat (penasehat hukum).(Nasional, 2008; Wignjosubroto, 2008) Bahkan ditemukan fakta bahwa banyak masyarakat di Kecamatan Mojogedang, Kabupaten Karanganyar takut berhadapan dengan hukum dikarenakan minimnya pengetahuan hukum dan mahalnya biaya beracara. Oleh karea hal tersebut beranjak dari sebuah pemahaman yang keliru, Tim Pengabdian Hukum Kepada Masyarakat kemudian merasa perlu menyelenggarakan sebuah kegiatan pengabdian masyarakat yang berkenaan dengan bantuan hukum gratis yang dapat diakses oleh masyarakat umum khususnya bagi masyarakat yang tidak mampu.

Dalam hal ini pengabdian masyarakat berbentuk sosialiasi hukum atau penyuluhan hukum, yang secara definitif penyuluhan hukum adalah salah satu kegiatan penyebarluasan informasi dan pemahaman terhadap norma hukum dan peraturan perundang-undangan yang berlaku guna mewujudkan dan mengembangkan kesadaran hukum masyarakat sehingga tercipta budaya hukum dalam bentuk tertib dan taat atau patuh terhadap norma hukum dan peraturan perundang-undangan yang berlaku demi tegaknya supremasi hukum.(Kemenkumham, 2007) 
Perlu disampaikan bahwa bantuan hukum adalah jasa hukum yang diberikan oleh Pemberi Bantuan Hukum secara cuma-cuma kepada Penerima Bantuan Hukum. Mengenai Penerima Bantuan Hukum sendiri ialah orang atau kelompok orang miskin. Dalam hal ini menurut peraturan perundangundangan Penerima Bantuan Hukum ialah harus memenuhi kriteria yang meliputi setiap orang atau kelompok orang miskin yang tidak dapat memenuhi hak dasar secara layak dan mandiri. Perihal hak dasar sendiri pun meliputi hak atas pangan, sandang, layanan kesehatan, layanan pendidikan, pekerjaan dan berusaha, dan/atau perumahan.

Dari hal demikian itu yang pada akhirnya menjadi salah satu upaya Tim Pengabdian Kepada Masyarakat untuk membantu memberikan pemahaman terkait bantuan hukum dengan melalui program penyuluhan hukum mengenai bantuan hukum. Adapun tujuan dari kegiatan penyuluhan hukum tersebut adalah untuk memberikan respon atas kegelisahan masyarakat di Kecamatan Mojogedang Kabupaten Karanganyar.

\section{METODE}

Kegiatan penyuluhan hukum di Desa Mojogedang, Kecamatan Mojogedang Kabupaten Karanganyar ini, dalam pelaksanaannya dibagi menjadi dua tahap, yaitu:

1. Tahap pertama. Sosialisasi pada masyarakat Desa Mojogedang dengan mengundang aparatur desa di Kecamatan Mojogedang lainnya terkait rencana dan program penyuluhan hukum. Pada tahap ini, masyarakat diminta untuk hadir dan mengikuti secara seksama pengarahan berkenaan dengan materi bantuan hukum, agar tujuan diadakannya kegiatan dapat tercapai secara maksimal.(Soekanto, 1986)

2. Tahap kedua. Konsultasi dan Pendampingan hukum pada masyarakat di Desa Mojogedang, Kecamatan Mojogedang, bilamana masyarakat Mojogedang sedang berhadapan dengan sebuah kasus hukum dapat untuk dikonsultasikan kepada Tim Pengabdian Masyarakat. Dan jika masyarakat tersebut ingin mendapatkan bantuan hukum secara gratis maka dapat melampirkan syarat SKTM sebagai bukti masuk kategori masyarakat miskin.

\section{HASIL DAN PEMBAHASAN}

Sebelum dilakukan pembahasan maka perlu dijelaskan terlebih dahulu letak geografis dan sosial Desa Mojogedang, Kecamatan Mojogedang, Kabupaten Karanganyar untuk mengetahui pentingnya pelaksanaan penyuluhan hukum,

\section{Letak Geografis}

Desa Mojogedang merupakan salah satu desa dari 13 (tiga belas) desa yang berkedudukan di Kecamatan Mojogedang yang mana Kecamatan Mojogedang sendiri merupakan salah satu kecamatan dari 17 (tujuh belas) kecamatan yang ada di Kabupaten Karanganyar. Luas wilayah Kecamatan Mojogedang adalah 53,31 km2 dengan ketinggian rata-rata $380 \mathrm{~m}$ di atas permukaan laut.(BK Karanganyar, 2019)

Batas wilayah Kecamatan Mojogedang :

Sebelah Utara $\quad$ : Kab. Sragen

Sebelah Selatan $\quad:$ Kec. KaranganyardanKecKarangpandan

Sebelah Barat $\quad$ : Kec. Tasikmadu

Sebelah Timur $\quad$ : Kec. NgargoyosodanKecKarangpandan

\section{Sosial}

a) Mata Pencaharian

Sesuai dengan kondisi alam Kecamatan Mojogedang yang pegunungan, maka sebagian besar penduduknya mempunyai mata pencaharian di sektor pertanian (petani sendiri dan buruh tani). Kemudian sebagai buruh industri/karyawan swasta, buruh bangunan dan pedagang. Selebihnya adalah sebagai pengusaha, di sektor pengangkutan, PNS/TNI/Polri, pensiunan, jasa-jasa dan lain-lain.(BK Karanganyar, 2019)

Berdasarkan data yang diperoleh dengan mayoritas penduduk di Desa Mojogedang adalah petani maka pemahaman atas hukum di Desa Mojogedang sangatlah minim, sehingga memang 
penting untuk dilakukan penyuluhan hukum yang menjadi kebutuhan masyarakat Desa Mojogedang agar lebih memahami bantuan hukum.

b) Sarana Perekonomian

Guna menunjang laju perekonomian di Desa Mojogedang pada tahun 2015 terdapat pasar desa 5 unit, toko/warung kelontong 450 unit, kedai/Warung makan 239 unit, KUD 2 unit, bank umum 3 unit, dan BPR 2 unit. Di samping itu di Kecamatan Mojogedang terdapat industri micro sebanyak 935 unit.(BK Karanganyar, 2019) Hal tersebut adalah sarana penunjang untuk menciptakan kesejahteraan bagi masyarakat Desa Mojogedang. Dari padangan perkonomian ini Tim Pengabdian Kepada Masyarakat menyebut masyarakat Desa Mojogedang Kecamatan Mojogedang Kabupaten Karanganyar perlu memahami bantuan hukum dan layanan yang dapat diakses sebagai penunjang kegiatan ekonomi masyarakatnya.

\section{Pelaksanaan Penyuluhan Bantuan Hukum}

Kegiatan Penyuluhan Bantuan Hukum ini dilaksanakan oleh Tim Pengabdian Kepada Masyarakat bekerja sama dengan Aparatur Desa Kecamatan Mojogedang dan Lembaga Mitra pada hari Kamis tanggal 25 Februari 2021 pukul 09.00 - 14.00 WIB yang bertempat di Aula Kecamatan Mojogedang, Kabupaten Karanganyar.

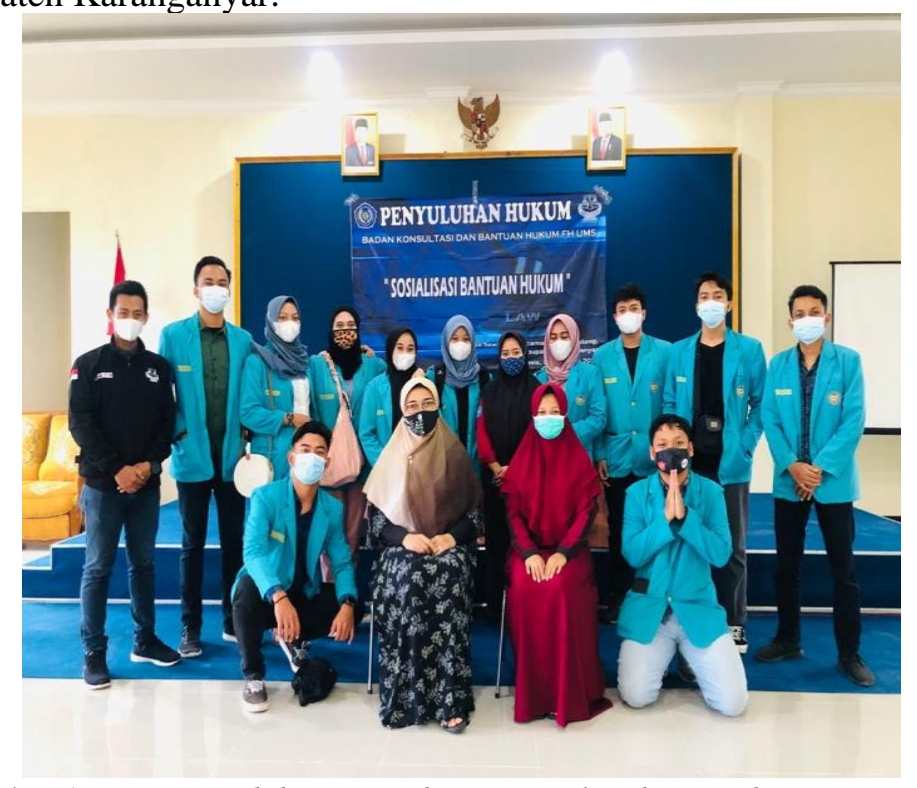

Gambar 1. Tim Pengabdian Kepada Masyarakat dan Lembaga Mitra

Penyuluhan hukum dihadiri oleh perwakilan aparatur desa yang terdiri dari Kepala Desa dan Sekretaris Desa di wilayah Kecamatan Mojogedang dan perwakilan warga Mojogedang. Materi yang disampaikan mengenai bantuan hukum bagi masyarakat miskin atau tidak mampu sesuai dengan Undang-Undang No 16 tahun 2011 tentang Bantuan Hukum. Yang mana Undang-Undang ini telah sesuai dengan tujuan negara yang terdapat pada Sila ke-5 Pancasila yaitu Keadilan sosial bagi seluruh rakyat Indonesia, yang bermakna bahwa keadilan tidak memandang status termasuk status ekonomi pelakunya. Upaya meratakan keadilan di masyarakat tersebutlah yang menjadi semangat melakukan perubahan di bidang penegakan hukum, salah satunya adalah memberikan akses keadilan bagi masyarakat miskin.

Hal tersebut telah diuraikan dalam paparan sosialisasi bantuan hukum (penyuluhan hukum) yang dilaksanakan di Desa Mojogedang Kecamatan Mojogedang Kabupaten Karanganyar. 


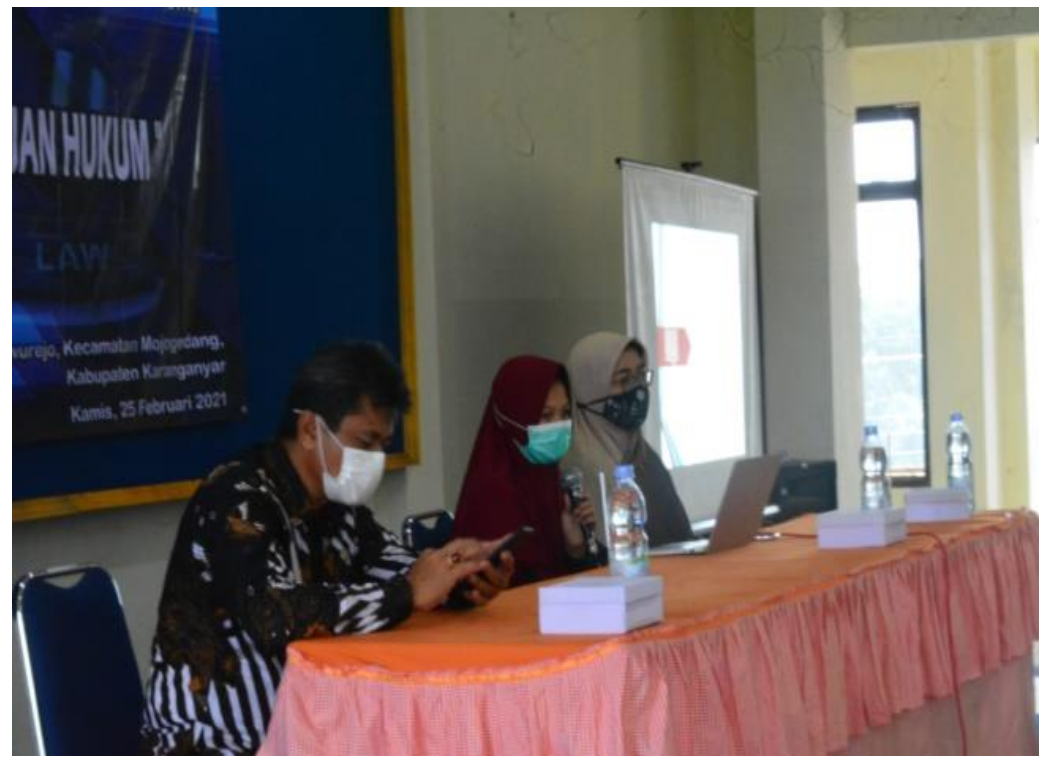

Gambar 2. Pemanyampain Materi Oleh Pemateri Dalam Penyuluhan Hukum

Adapun dalam kegiatan penyuluhan tersebut telah disampaikan beberapa pembahasan yang meliputi:

1. Latar belakang dibentuknya Undang-Undang Nomor 16 Tahun 2011 Tentang Bantuan Hukum, yang mana dalam materi ini Tim Pengabdian Kepada Masyarakat menjelaskan mengenai keadaan hukum ketika belum muncul Undang-Undang No 16 tahun 2011 tentang Bantuan Hukum, yang mana proses hukum sangat membebani masyarakat dan hanya dapat diakses dengan biaya yang sangat mahal, maka perlu ada jaminan keadilan untuk masyarakat miskin atau masyarakat dengan katagori tidak mampu.

2. Pengertian dari bantuan hukum menurut Undang-Undang No 16 tahun 2011 tentang Bantuan Hukum adalah jasa hukum yang diberikan oleh pemberi bantuan hukum secara cuma-cuma kepada penerima bantuan hukum.

3. Asas-asas bantuan hukum berdasarkan Undang-Undang No 16 tahun 2011 tentang Bantuan Hukum adalah sebagai berikut : asas keadilan, asas persamaan kedudukan didalam hukum, asas keterbukaan, asas efisiensi, asas efektivitas dan asas akuntabilitas. Asas-asas tersebut yang menjadi dasar pemberian layanan dan pelaksanaan bantuan hukum yang dapat diakses oleh masyarakat miskin atau tidak mampu.

4. Tujuan diadakannya bantuan hukum menurut Undang-Undang No 16 tahun 2011 tentang Bantuan Hukum yaitu sebagai berikut :

a. menjamin dan memenuhi hak bagi Penerima Bantuan Hukum untuk mendapatkan akses keadilan

b. mewujudkan hak konstitusional segala warga negara sesuai dengan prinsip persamaan kedudukan di dalam hokum

c. menjamin kepastian penyelenggaraan Bantuan Hukum dilaksanakan secara merata di seluruh wilayah Negara Republik Indonesia

d. mewujudkan peradilan yang efektif, efisien, dan dapat dipertanggungjawabkan

dari tujuan tersebut di atas maka dapat diketahui bahwa pemerintah memiliki upaya untuk melakukan perubahan dalam dunia hukum dengan membuka akses keadilan bagi masyarakat miskin agar mendapatkan pelayanan yang sama yaitu didampingi oleh pengacara atau advokat di litigasi dan atau mendapatkan informasi mengenai hukum yang dihadapinya melalui jalur pelayanan non litigasi.

5. Ruang lingkup bantuan hukum. Bantuan hukum yang dapat diakses oleh masyarakat miskin atau tidak mampu sangatlah banyak yang terdiri dari pelayanan bantuan hukum litigasi dan pelayanan bantuan hukum non litigasi. Pada Pelayanan bantuan hukum litigasi, masyarakat dapat mengakses pendampingan pengacara atau advokat secara gratis selama proses hukum berlangsung dan melakukan upaya hukum untuk mencari keadilan. Sedangkan untuk pelayanan non litigasi, masyarakat berhak mendapatkan fasilitas mediasi, konsultasi, negosiasi, investigasi, dan lain-lain. 
Keseluruhan pelayanan yang diberikan oleh pemberi bantuan hukum tersebut harus gratis atau cuma-cuma karena pemberi bantuan hukum sudah mendapatkan pembiayaan dari pemerintah.

6. Kriteria, syarat, hak, dan kewajiban dari penerima bantuan hukum. Dalam materi ini dijelaskan dan ditekankan salah satu syarat untuk menjadi penerima bantuan hukum secara cuma-cuma adalah masyarakat masuk kriteria miskin atau tidak mampu yang dibuktikan dengan Surat Keterangan Tidak Mampu yang dikeluarkan oleh Kelurahan /Desa. Jika sudah memiliki Surat Keterangan Tidak Mampu ini maka dapat mengakses pelayanan bantuan hukum yang tersedia di Lembaga bantuan hukum yang telah terakreditasi.

7. Sesi diskusi dan konsultasi dengan Tim Pengabdian Kepada Masyarakat yang bekerjasama dengan Lembaga mitra. Pada sesi ini masyarakat dan aparatur desa di beri kesempatan untuk menyampaikan masalah hukum yang dihadapinya atau ditemukan di masyarakat sehingga dapat dijelaskan cara penyelesaiannya oleh lemabaga mitra. Dari setiap desa menyampaikan permasalahan hukum yang dihadapi masing-masing dan dapat disimpulkan bahwa masyarakat Desa Mojogedang pada khususnya dan masyarakat Kecamatan Mojogedang pada umumnya belum mengetahui haknya untuk dapat mengakses bantuan hukum gratis dari pemerintah sehingga ketika berhadapan dengan permasalahan hukum merasa kebingungan harus melakukan apa dan mengadu kesiapa.

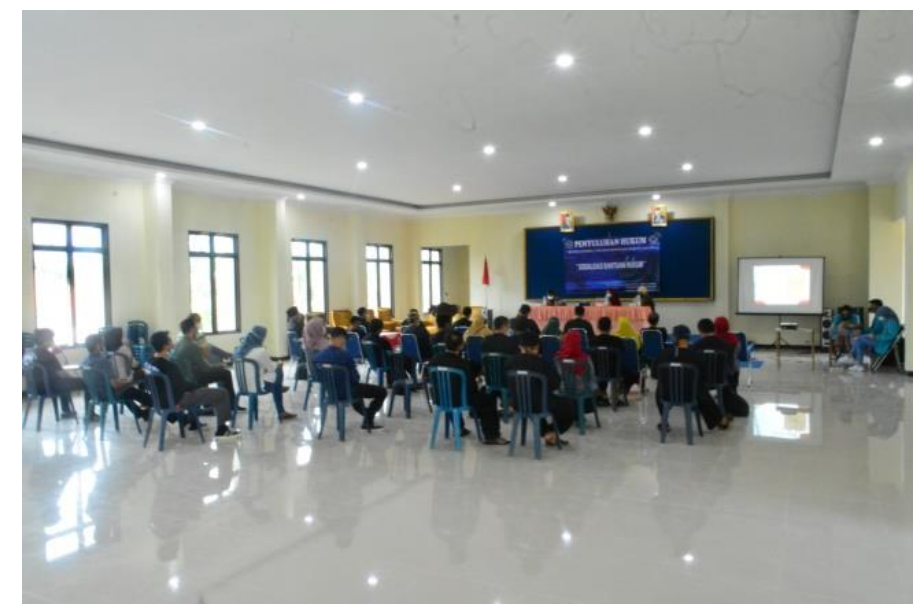

Gambar 3. Kegiatan Sosialisasi Bantuan Hukum

Lawrence M. Friedman mengatakan bahwa sistem hukum, ada beberapa komponen unsur hukum, yaitu: (Friedman, 2001)

1. Sistem hukum mempunyai struktur. Sistem hukum terus berubah, namun bagian-bagian sistem itu berubah dalam kecepatan yang berbeda, dan setiap bagian berubah tidak secepat bagian tertentu lainnya;

2. Sistem hukum mempunyai substansi, yaitu berupa aturan, norma, dan pola perilaku nyata manusia yang berada dalam sistem itu;

3. Sistem hukum mempunyai komponen budaya hukum, yaitu sikap manusia terhadap hukum dan sistem hukum itu sendiri, seperti kepercayaan, nilai, pemikiran serta harapannya.

Lawrence Friedman menjelaskan lebih lanjut bahwa budaya atau kultur hukum merupakan faktor nilai yang menimbulkan perbedaan dalam kehidupan hukum dalam masyarakat, sehingga kultur hukum merupakan sikap-sikap dan nilai-nilai yang dimiliki oleh masyarakat yang berhubungan dengan hukum dan lembaga-lembaganya, baik yang bersifat positif maupun negatif.(Warassih, 2005) Pemerintah melalui substansi hukum yaitu Undang-Undang No 16 tahun 2011 tentang Bantuan Hukum sudah berupaya memberikan fasilitas bantuan hukum bagi masyarakat miskin atau tidak mampu untuk mengakses keadilan. Dan penegak hukum yang dalam hal ini pengacara/ advokat sudah ikut serta dalam Lembaga Bantuan Hukum yang terakreditasi untuk memberikan pelayana cuma-cuma kepada masyarakat. Maka dari itu harapan dari diadakannya pengedukasian tentang bantuan hukum ini mampu membuka pemikiran yang mempengaruhi budaya dan kultur hukum di Desa Mojogedang Kecamatan Mojogedang Kabupaten Karanganyar, yang mana mengubah pola pikir negatif yang semula "seseorang tidak mempunyai finansial yang baik maka tidak dapat memperoleh sebuah bantuan hukum untuk mengakses keadilan" berubah menjadi "setiap orang di Indonesia walaupun 
tidak mempunyai kekuatan finansial sekalipun mempunyai hak untuk memperoleh bantuan hukum yang layak dan baik".

\section{SIMPULAN}

Kesimpulan dan hasil dari pelaksanaan kegiatan sosialisasi bantuan hukum di Desa Mojogedang, Kecamatan Mojogedang, Kabupaten Karanganyar adalah: (1) Masyarakat Desa Mojogedang telah memahami berbagai aspek dalam memperoleh bantuan hukum. (2) Masyarakat Desa Mojogedang telah memahami bahwa masyarakat tidak mampu juga dapat mengakses bantuan hukum secara gratis di Lembaga Bantuan Hukum yang terakreditasi dengan menunjukkan surat keterangan tidak mampu (SKTM) yang dikeluarkan oleh kepala desa setempat.

\section{UCAPAN TERIMA KASIH}

Ucapan terimakasih disampaikan kepada Aparatur Desa dan Masyarakat di Kecamatan Mojogedang, Kabupaten Karanganyar dan teman-teman magang di BKBH FH Universitas Muhammadiyah Surakarta.

\section{DAFTAR PUSTAKA}

BPHN. (2008). Laporan Forum Koordinasi Nasional Dalam Rangka Pelaksanaan Kegiatan Penyuluhan Hukum Pusat dan Daerah. Surabaya.

BPHN (2008). Kegiatan Penyuluhan Hukum Bagi Peningkatan Kesadaran Hukum Masyarakat. 1-95. Diambil dari https://bphn.go.id/data/documents/lit_penyuluhan_hukum.pdf

BK Karanganyar (2019). Kecamatan Mojogedang Dalam Angka 2019. In Kecamatan Mojogedang Dalam Angka 2019 (hal. 1-91). Karanganyar: BPS Kabupaten Karanganyar.

Friedman, L. M. (2001). Sebuah Pengantar Hukum Amerika. Jakarta: PT Tata Nusa m.

Kemenkumham. Peraturan Menteri Hukum dan HAM RI Nomor: M-01.PR.08.10 Tahun 2007 Tentang Perubahan atas Peraturan Menteri Hukum dan Hak Asasi Manusia RI Nomor : M-01.PR.08.10 Tahun 2006 Tentang Pola Penyuluhan Hukum Tentang Pola Penyuluhan Hukum. , (2007).

Laili, U. (2016). Kebijakan Penyuluhan Hukum Pada Kanwil Kemenkumham Kaltim. Diambil darihttp://download.portalgaruda.org/article.php?\%0Aarticle=183588\%0A\&val=638 3\&title=KEBIJAKAN\%25\%0A20PENYULUHAN\% 2520HUKUM\%2520\% 2520P \%0AADA\%2520KANWIL\%2520KEMENTERIAN\%25\%0A20HUKUM\%2520DA N\%2520HAM\%2520KALIM\%0AANTAN\%2520TIMUR

Rahardjo, S. (2006). Hukum Dalam Jagat Ketertiban. Jakarta: UKI Press.

Soekanto, S. (1986). Beberapa Cara dan Mekanisme Dalam Penyuluhan Hukum. Jakarta: Pradnya Paramita.

Sudjana. (2016). Penyuluhan Hukum Dalam Upaya Peningkatan Kesadaran Hukum Berlalulintas Melalui Pemahaman Terhadap Isi Undang-Undang Nomor 22 Tahun 2009. Jurnal Pendidikan Ilmu Sosial, 25(2), 1-14. Diambil dari https://ejournal.upi.edu/index.php/jpis/issue/view/702 
Warassih, E. (2005). Pranata Hukum Sebuah Telaah Sosiologis. Semarang: PT Suryandaru Utama.

Wignjosubroto, S. (2008). Hukum dalam Masyarakat, Perkembangan dan Masalah Sebuah Pengantar Kearah kajian Sosiologi Hukum. Malang: Bayumedia Publishing.

Undang Undang Dasar 1945.

Undang Undang Nomor 16 Tahun 2011 Tentang Bantuan Hukum

Undang-Undang Nomor 12 Tahun 2012 tentang Pendidikan Tinggi.

Undang Undang Nomor 6 Tahun 2014 Tentang Desa. 